\title{
Future Pathways in Implementing the Teaching Personal and Social Responsibility Model in Spain and Portugal \\ Rutas futuras en la Implementación del modelo de enseñanza de la responsabilidad personal y social en España y Portugal \\ *Fernando Santos, **Rui Neves, ***Melissa Parker \\ *Polytechnic Institute of Viana do Castelo (Portugal), **University of Aveiro (Portugal), *** University of Limerick (Irlanda)
}

\begin{abstract}
Throughout the last two decades, researchers in Spain and Portugal have utilised the Teaching Personal and Social Responsibility (TPSR) to generate responsibility outcomes in Physical Education (PE) and further understand TPSR application. In order to move the field forward in these contexts, projections as to future of TPSR and guidelines for researchers are needed. The purpose of this article is to provide insights for expanding our knowledge of TPSR in Spain and Portugal. Although research on TPSR has provided useful insights on the processes and outcomes associated with TPSR-based programming, research exploring life skills transfer processes is needed. Further, an understanding of the broader socio-cultural forces that exist in schools and their influence on TPSR could provide valuable insight. Finally, few investigations have included young children. Moving forward, these insights may help expand future research by fostering reflection about TPSR in Spain and Portugal.

Keywords: personal development, curriculum, social skills, values, physical education.

Resumen. A lo largo de las dos últimas décadas, los investigadores en España y Portugal han utilizado el Responsabilidad personal y social en la enseñanza (TPSR) para generar resultados de responsabilidad en educación física (PE) y comprender mejor la aplicación del TPSR. Para avanzar el campo en estos contextos, se necesitan proyecciones sobre el futuro del TPSR y las pautas para los investigadores. El propósito de este artículo es proporcionar información para ampliar nuestro conocimiento del TPSR en España y Portugal. Aunque la investigación sobre el TPSR ha proporcionado información útil sobre los procesos y resultados asociados con las intervenciones basadas en TPSR, es necesaria investigación que explore los procesos de transferencia de habilidades para la vida. Además, una comprensión de las fuerzas socioculturales más amplias que existen en las escuelas y su influencia en la programación de TPSR podría proporcionar información valiosa. Finalmente, pocas investigaciones han incluido niños pequeños. En el futuro, estas ideas pueden ayudar a expandir la investigación al fomentar una reflexión sobre TPSR en España y Portugal.
\end{abstract}

Palabras clave: desarrollo personal, currículo, habilidades sociales, valores, educación física.

\section{Introduction}

Worldwide, quality physical education (PE) has been considered paramount for children and youth to attain motor competence and become physically active throughout the life span (McLennan \& Thompson, 2015). Additionally, $\mathrm{PE}$ is a context that could be conducive to personal and social responsibility development and provide the necessary foundation for children and youth to become active contributors to society (Brustad \& Parker, 2005). While often accepted, these goals have not been unproblematic as documentation of their achievement is difficult due to the fact that teaching toward these types of outcomes is challenging (Pill, Penney, \& Swabey, 2012).

Positive youth development (PYD) has been considered a valuable approach to understand youth's developmental process in a vast array of settings such as sport (Damon, 2004; Theokas et al., 2005). PYD focuses on asset-building premises which value individuals' strengths and potential to strive in life instead of just focusing on solving youth's developmental challenges (Lerner, Almerigi, Theokas, \& Lerner, 2005). Within a PYD approach, several outcomes have been conceptualized. More specifically, personal and social responsibility development has been considered as a desired outcome of PYD programming implying that PE teachers deliberately focus on developing life skills such as respect, perseverance, self-direction, and leadership (Hellison, 2011;

Fecha recepción: 20-05-19. Fecha de aceptación: 17-11-19 Fernando Santos

fsantos@ese.ipp.pt
Hellison, Martinek, \& Cutforth, 1996). This approach has been considered crucial in PE due to the fact youth face multiple social challenges (Vivas, Gómez, Bartoll, \& Miravet, 2017; Valero, Martínez, \& Botella, in press) and need support to learn life skills through PE (Cascales \& Prieto, 2019; Molina, 2018). These life skills are viewed as positive skills that should be taught and intentionally transferred from PE to nonsportive domains (Gould \& Carson, 2008). Personal and social responsibility development has often been associated in the PE literature with Hellison's TPSR conceptualization (2011) that has offered unique content and intentional strategies for youth to flourish. Although in many occasions Hellison's conceptualization (2011) has been referred to as 'TPSR model and/or program', TPSR could be considered as a worldview involving a specific way of thinking about what is important in PE. Therefore, we will use the term 'TPSR' throughout this article to describe Hellison's worldview and avoid a more narrow approach that considers TPSR simply a model and/or program.

\section{Theoretical Paradigms and Hellison's TPSR}

Hellison's TPSR was created based on a PYD perspective towards youth development. Within a PYD approach, as stated, youth are seen as assets to be developed rather than problems to be fixed (Damon, 2004) which represents a paradigm shift for many teachers, coaches and policy makers. Clinical psychology tenets has mainly focused on reducing deficit and helping individuals overcome developmental issues by removing negative behaviors (Seligman \& Csikszentmihályi, 2000). Thus, PYD is grounded on pedagogical principles that derived from positive psychology 
(Seligman \& Csikszentmihályi, 2000) that moves away from clinical psychology tenets because the focus is placed on youth's contributions for their own development and on skill-building. PYD and positive psychology principles have become popular in a vast array of setting such as sport and physical education (Brustad \& Parker, 2005).

Based on previous notions, PYD through sport (Holt, 2016) is intended to foster meaningful experiences for youth in sport through carefully designed experiences that create a developmentally sound platform conducive to life skills development and transfer. Within a PYD through sport perspective, many pedagogical models and intervention programs have been designed in order to help PE teachers and other stakeholders foster PYD outcomes. For example, the sport education model has been designed to use competition to foster motor competency, social development and enthusiasm towards sport (Gordon, 2009; PuenteMaxera, Mahedero-Navarrete, Méndez-Giménez, \& Ojeda, in press). This model uses competition as a vehicle to foster youth's holistic development and a vast array of learning outcomes through physical education. On the other hand, TPSR has been framed as way of thinking about youth development and physical education. Further, TPSR could viewed through positive psychology tenets as well as developmental systems theory (Ford \& Lerner, 1992) and self-determination theory principles (Deci \& Ryan, 2008). Selfdetermination theory tenets, specifically autonomy, relatedness, and competency, have been used to understand the effectiveness of TPSR interventions (Ward, Parker, Henschel-Pellett, \& Perez, 2012). On this notion, Ford's (1992) developmental systems theory also aligns with TPSR principles by recognizing the need to consider the role played by environment, genetics and individual predispositions to foster positive developmental outcomes. Hence, several theoretical paradigms align with Hellison's TPSR key principles and have been used by researchers across the globe to further understand the impact of TPSR on youth.

\section{Overview of Hellison's TPSR}

Based on previous notions, the primary focus of TPSR is to help youth learn how to become responsible for themselves and others through PE. This premise is crucial to many programs that consider PE to be a developmentally focused platform that may, secondarily, lead to a broader range of outcomes such as physical development (Hellison, 2011). Within TPSR, PE is used as tool to attain a set of specific outcomes through five responsibility levels, specifically: (a) respect for the right of feeling of others; (b) participation and effort; (c) self-direction; (d) leadership/ caring for others; and (d) transference of responsibility model goals to other life domains (Hellison, 2011). Each responsibility level provides guidelines for PE teachers to define responsibility objectives and select appropriate activities and strategies. Based on developmental systems theory (Ford \& Lerner, 1992), each responsibility level should be viewed as dynamic. Throughout time, individuals may situate themselves in different responsibility levels which demands a constant focus on how to provide developmentally sound experiences and relevant positive outcomes (Walsh, Ozaeta, \& Wright, 2010). Research on TPSR has been conducted across a range of diverse settings such as afterschool programs (e.g., Martinek, Schilling, \& Hellison, 2006) and sport-based youth development programs (e.g., Jacobs \& Wright, 2017) and considered effective in each situation (Caballero-Blanco, 2015). This research has been crucial to develop evidence-based recommendations for PE teachers and understand how to increase the quality of PEbased programs that aim to impact youth's life skills and values.

\section{Purpose}

In order to increase our understanding about research on the TPSR, novel research questions and designs could be raised and potentially enable a more holistic understanding about the processes of TPSR outcomes. In the present article, we attempt to provide a reflection about the research conducted regarding TPSR in Spain and Portugal, and suggest evidence-based research recommendations that may, potentially, help inform future studies. Therefore, the purpose of this article is to provide insights on potential research recommendations for expanding our knowledge of the TPSR in Spain and Portugal.

\section{Previous Research on TPSR}

\section{TPSR interventions and life skills transfer processes}

Research conducted with TPSR has provided relevant insights on the efficacy of TPSR-based programs and on the processes (i..e, contextual adaptations) related to implementing TPSR constructs in a range of contexts such as adapted physical activity programs (Wright, Jacobs, Ressler, \& Jung, 2016; Wright, White, \& Gaebler-Spira, 2004). Considering past research on the TPSR, it is important to state that numerous studies (Escartí, Gutiérrez, Pascual, \& Marín, 2010) have focused on youth participants' responsibility outcomes as a result a TPSR-based intervention programs. For instance, Escartí et al. (2010) analysed the effects of a TPSR intervention program on 30 Spanish at-risk adolescents with 13 and 14 years old and found the program improved the participants improved their responsibility behaviors. In the Portuguese context, several studies have been conducted to understand youth participants' responsibility outcomes within the school setting (Correia, 2007; Côrte-Real, 2011; Regueiras, 2006). Subsequently, Pozo, Grao-Cruces, and Pérez-Ordás (2018) conducted a review of research on the TPSR within physical education and highlighted that youth participants' outcomes have been extensively explored throughout the last decades. It is reasonable to state that most research has attempted to develop outcome evaluations of TPSR-based programs and understand the effects of teaching practices on student outcomes (Caballero-Blanco et al., 2013; Escartí et al., 2006; Escartí, Llopis-Goig, \& Wright, 2018; Escartí et al., 2012). Previous studies (Escartí et al., 2010; Santos, Corte-Real, Regueiras, Wright, Dias, \& Fonseca, 2019) have used the Tool for Assessing Responsibility-based Education (TARE) to analyze PE teachers responsibility behaviors and student outcomes. This has been one the most used tools within the TPSR literature both in Portugal and Spain (Escartí, Wright, 
Pascual, \& Gutiérrez, 2015). This approach to evaluating TPSR interventions has provided information on teachers TPSRrelated behaviors and/or students responsibility outcomes. However, there has been a call, on a global scale, for further reflections about how TPSR-based programs may lead to specific responsibility outcomes and the process of implementing TPSR (Barker \& Forneris, 2012).

It is unquestionable that many studies that have conducted outcome evaluations have provided valuable insight (Caballero-Blanco et al., 2013). Previous guidelines on PYD assessment (MacDonald \& McIsaac, 2016) have supported this notion and acknowledged the need for this type of investigations in order to move the field forward. Outcome evaluations involve collecting data from youth participants and may help understand the impact of TPSRbased programs. For instance, the personal and social responsibility questionnaire has been used both in Portugal and Spain (Martins, Rosado, Ferreira, \& Biscaia, 2015; Ponsoda, 2014) to measure students perceptions about TPSR. Concerning the way outcome evaluations have been operationalized, there are issues that might enhance our understanding about the effectiveness of TPSR, specifically how life skills transfer is investigated. As stated previously, TPSR is guided by a strong life skills focus as the final and more complex objective is to help youth transfer life skills to other life domains. Several studies conducted in Canada and United States of America have tried to understand the processes behind facilitating life skills transfer (Bean, Kramers, Forneris, \& Camiré, 2018; Jacobs \& Wright, 2017; Pierce, Gould, \& Camiré, 2017) which could provide direction for future studies focused on life skills transfer within TPSR. Bean et al. (2018) proposed an implicit/explicit continuum of life skills development and transfer in which PE teachers' ability to explicitly foster life skills transfer is seen as a dynamic process. This explicit approach to life skills transfer implies that PE teachers develop systematic opportunities for students to learn, internalize, apply, and transfer life skills. On the other hand, an implicit approach to life skills transfer does not consider any of these features as PE teachers rely on teachable moments and a PYD climate. Within the TPSR literature, several studies have used an implicit approach towards life skills transfer (e.g., Jung \& Wright, 2012) and, in some cases, stated this decision was made due to specific adaptations made to fit a specific socio-cultural context and participants' developmental needs. In the Portuguese and Spanish context, an implicit approach towards life skills transfer has been, in most cases, used (Escartí et al., 2012; Pavão, Santos, Wright, \& Gonçalves, 2019; Santos, CorteReal, Regueiras, Dias, \& Fonseca, 2017) and investigations have paid less attention to explicit life skill transfer processes.

Although TPSR alludes to the need of situating youth participants in a specific level of responsibility (Escartí, Buelga, Gutiérrez, \& Pascual, 2009; Martinek \& Hellison, 2009), it is potentially debatable that life skills transfer may only be explicitly investigated once youth participants reach the final level of responsibility included in the model (i.e., Level V, transference). We raise this argument due to the fact that several studies have focused on the initial four levels of responsibility. While providing a valuable contribution on how these outcomes may occur as a result of high quality
TPSR programs, an in-depth analysis of life skills transfer processes still largely remains to be explored. Within the TPSR literature, most studies have not considered how youth participations apply life skills beyond the gym and have not included stakeholders crucial in this process such as parents and/or meaningful adults. There are few studies in Portugal and Spain that have included parents, youth and other stakeholders to understand life skills transfer processes through longitudinal designs (Merino-Barrero, Pedreño, Valenzuela, \& Fernandez-Rio, 2019; Ponsoda, 2014). Santos et al. (in press) explored the impact of a TPSR program on transference of responsibility goals within a preschool setting and included children and parents voices. We should have in mind that life skills transfer is contingent on the setting in which transfer actually occurs (e.g., school, family) and on the support given from significant others (e.g., PE teachers, parents) which could guide research designs (Bean et al., 2018).

Further, many outcome evaluations of TPSR interventions have attempted to understand the impact on students, but have not provided insight on individual student responses to TPSR programming. Recently, Melo, Santos, Wright, Sá, Saraiva (in press) argued the need to understand how TPSR-based programs impact students responsibility behaviors differently. One of Hellison's (2011) premises with TPSR is that youth have diverse developmental needs and PE teachers and/or educators should develop differentiated instruction techniques to teach them skills they need to flourish. Nevertheless, no studies found within this literature review investigated how TPSR impacted each youth participant differently and the use of differentiated instruction techniques.

\section{Social influences on teaching for responsibility} outcomes

Most research on the TPSR conducted in various settings and/or countries has considered PE teachers pivotal stakeholders in successful TPSR implementations (Brustad \& Parker, 2005; Ruiz et al., 2006; Santos et al., 2015). As such, several studies have analysed PE teachers' efforts towards TPSR and highlighted their role in creating high quality programs by implementing a sound set of responsibilitybased objectives, strategies, and activities (Jung \& Wright, 2012; Martinek et al., 2006; Pavão et al., 2019; Regueiras, 2012). A teacher and student-centered approach has dominated the majority of studies with TPSR as teaching and learning have been understood through a dyadic analysis of teacher-student interactions (Martins et al., 2015; Pozo, Grao-Cruces, \& Pérez-Ordás, 2018). Nevertheless, previous research has provided insight on how PE teachers are influenced by different contextual features such as the social forces imposed by other stakeholders who are part of the school system such as school managers (Parker \& Patton, 2017; Parker, Patton, \& Tannehill, 2017). More specifically, the time, and reflection needed to implement TPSR coupled with the lack of support to overcome challenges faced during TPSR implementation could make PE teachers disregard TPSR (Escartí et al., 2012). These social forces are also relevant to understand the processes of learning how to foster a TPSR mandate and sustaining a TPSR-based program throughout 
time (Hemphill, Templin, \& Wright, 2015). Further, these social forces are culturally situated and are dictated by educational systems. Several researchers, with particular attention to the work conducted in the Spanish context by Escartí, Gutiérrez, Pascual, and Wright (2013), have developed TPSR-focused teacher education programs to help PE teachers learn to implement TPSR. A core premise of these studies is the need to empower PE teachers to sustain a TPSR mandate in real world settings and overcome social pressures and challenges. A broader analysis of the social context in which PE teachers teach and apply the TPSR model could prove useful. On this notion, Beale (2012, p.260) reflecting on the implementation of a TPSR program highlighted the following:

I have learned that it is important to establish and work side by side with both national and community-based organizations, district representatives, grant representatives, school administrators, the athletic director, the pool operator and custodian, administrative assistants, facility and transportation personnel including the bus drivers, the students, and their parents. All of these efforts and more were taken to ensure the success of our program.

Despite the fact that this notion has been raised and discussed, there are still questions that remain answered. If TPSR-focused researchers wish to make a real world impact, there is the need to recognize and comprehend the complex social nature of teaching PE in schools. Further, it could be necessary to analyse the challenges faced by PE teachers such as dealing with PE teachers who do not value TPSR, and school managers that only value psychomotor outcomes and do not support TPSR. Using socialization theory (Lawson, 1983ab) to comprehend the complexities of TPSR implementation may help researchers understand the mechanisms (i..e, facilitators, barriers) that make TPSR feasible or not (Duerden \& Witt, 2012) which could have implications for TPSR-focused teacher training in Portugal and Spain.

Several frameworks (e.g., Parker, Patton, \& Tannehill, 2017) have provided insight on the social influences behind teachers' learning process and highlighted that other key stakeholders within the school system play a role in continuous professional development and could serve as facilitators for TPSR implementation. Although the TPSR model has been included in the PE curriculum in certain countries such as New Zealand (Gordon, Thevenard, \& Hodis, 2012), again socialization theory could be used to understand how each member of a school organization influences PE teachers' ability to foster responsibility outcomes and creates solid grounds for sound TPSR programs. Power relationships within the school system could also be considered while analyzing the creation, implementation and sustainability of TPSR-based programs in real world settings (Coakley, 2016). PE teachers, despite mastering crucial pedagogical skills, fidelity to the TPSR constructs might be weak and schools might play a role in helping PE teachers implement TPSR (Casey \& Dyson, 2009). The lack of support for TPSR implementation may hinder the creation and sustainability of TPSR implementation within a real teaching scenario (Whitley, Forneris, \& Barker, 2015). Thus, it might be beneficial to consider a reconceptualization of continuing professional development for TPSR implementation that considers focusing on PE teachers' learning paths, changing perspectives on TPSR, and related learning processes (Parker \& Patton, 2017). Learning should be viewed as a cooperative process and if a TPSR emphasis is to succeed over time it could be necessary to develop a school philosophy coherent with the premises of TPSR. This philosophy could be shared by all the stakeholders and teachers within different subject areas (Escartí, Llopis-Goig, \& Wright, 2018) to create opportunities for continuous professional development that emerges within the school system by itself (Ennis et al., 1999; Neves, 2017). To date, few research has explored these nuances within TPSR programming.

\section{TPSR interventions across contexts and age groups}

Currently, TPSR has expanded to several countries (including Spain, Portugal) (Santos et al., 2015) and settings (e.g., afterschool programs, coaching clubs) enabling an analysis of students' and PE teachers' experiences, and outcomes within different realities (Escartí et al., 2013; Santos et al., 2017; Walsh et al., 2010). Most studies have mainly focused on implementing TPSR within PE (Escartí et al., 2018; Escartí et al., 2012) and afterschool activities (Cecchini, Montero, \& Peña, 2003). Nevertheless, other studies have explored how TPSR may be used within youth sport (Santos, Corte-Real, Regueiras, Dias, \& Fonseca, 2017) and within teacher training programs (Alcalá, Río, Calvo, \& Pueyo, 2019). These intervention studies have mainly used quantitative or qualitative methods in an attempt to understand how TPSR may be used as mixed methods approaches were scarce (Camerino, Valero-Valenzuela, Prat, Sánchez, \& Castañer, 2019).

These studies have also provided necessary insight on the adaptations needed (e.g., responsibility-based strategies) to implement the TPSR with a vast array of populations such as underserved adolescent youth (Correia, 2007; Regueiras, 2006) and preschoolers (Pavão et al., 2019). In fact, TPSR experts have considered the need to explore a set of differentiated educational settings, specifically in childhood (Wright, Dyson, \& Moten, 2012). More specifically, TPSR has been considered effective within the school context because it enables PE teachers to more deliberately implement certain aspects of the curriculum (i.e., focused on personal and social development) and thus increase the possibilities of attaining more outcomes for children and youth across the developmental spectrum (Barker \& Forneris, 2012). In fact, most research in Portugal and Spain has focused on adolescent youth (Escartí, Gutiérrez, Pascual, \& Marín, 2010; Escartí et al., 2012) and/or children involved within primary school settings (ranging between 6 and 10 years old) (Santos et al., 2017). However, although it has been argued that a TPSR emphasis should be implemented beginning in childhood to highlight more responsibility outcomes (Martinek \& Hellison, 2016), few studies have explored how TPSR might be applied with preschool children that present emergent social and emotional learning needs (Pavão et al., 2019). Concurrently, TPSR-focused teacher training interventions are still scarce within contexts that involve children ranging between 3 and 10 years old that are at a critical developmental stage. 
Social and emotional learning (Durlak, Weissberg, Dymnicki, Taylor, \& Schellinger, 2011) has been considered crucial for children in order to help attain school readiness and prepare them for the social challenges related to school life. Additionally, social and emotional learning needs (Bakken, Brown, \& Downing, 2017; Hamre \& Pianta, 2005) and frameworks (Merrell \& Gueldner, 2010) have conceptualized childhood as a developmental stage crucial for children to learn a vast array of skills such as decisionmaking and empathy with support of appropriate curricula and teaching practices. These features align with the nature and scope of TPSR and could be investigated to understand how PE may contribute to the social and emotional learning process of preschool children. Research within preschool settings (i.e., children ranging between 2 and 5 years old) is still scarce in Portugal and Spain (Pavão et al., 2019) as most research has focused on adolescent youth (Escartí et al., 2012). Based on previous notions, preschool education in many European countries, including Portugal and Spain, is delivered by generalist teachers who are responsible for implementing PE and other content areas (e.g., math, sciences). In this sense, conceptualising and investigating TPSR within the broader context of social and emotional learning (SEL) (CASEL, n.d.) may provide a sense of pedagogical continuity and enable enhanced responsibility outcomes (Escartí et al., 2018). One might even argue that if a preschool teacher implements the TPSR as SEL within PE it could be difficult to disregard this approach in other content areas (Escartí et al., 2018).

Researchers have long attempted to further enhance our understanding of the processes behind program creation, implementation, and validation which has added insight on which to move the field forward (Martinek \& Hellison, 2016). In Portugal and Spain, efforts have been made to use TPSR and extend Hellison's (2011) legacy of helping children and youth become responsible for themselves and others. Further, researchers have taken solid steps to increase our knowledge about TPSR itself. However, in order to move the field forward in Portugal and Spain consideration of specific age groups and educational settings that have been less explored and may contribute to effectively introducing TPSR within the school curriculum.

\section{Conclusions}

In the present article, we aimed to provide insights for expanding our knowledge of TPSR in Spain and Portugal. We suggest that future research in these contexts considers the need of exploring life skills transfer processes, the existence of broader socio-cultural factors that influence TPSR programming, and the need to investigate TPSR implementation within preschool education. These three core lines of inquiry could be potentially used to enhance the knowledge base and move the field forward.

Life skills transfer processes are complex, but a core premise of TPSR programming. Thus, we urge researchers and stakeholders to focus on developing outcome evaluations that attempt to (a) explicitly focus on life skills transfer, (b) define life skills transfer goals and track youth participants ability to transfer life skills longitudinally, (c) engage multiple stakeholders involved in life transfer process such as parents, coaches and teachers within other content areas beyond PE, and (d) consider youth participants different responses to TPSR and ability to transfer life skills. Holistic perspectives on life skills transfer that reflect the complex nature of this process are needed to really understand how TPSR is making a difference beyond the scope of the program.

Social influences on TPSR should also be further investigated to enhance our understanding about how to maintain the effectiveness of TPSR-based programs. More specifically, it is relevant to understand how stakeholders (e.g., policy makers, other teachers) within specific sociocultural contexts influence teachers efforts to implement TPSR. Considering learning a cooperative process, teaching and learning TPSR is influenced by a broad range of actors that may prioritize or not TPSR and provide solid grounds for increasingly more effective TPSR programming. In addition, many TPSR interventions have been conducted by experts on TPSR and/or have included teacher training programs to help teachers develop the skills needed to foster TPSR. However, there is the need to understand how TPSR is still a feasible endeavour beyond TPSR interventions and/ or teacher training programs. If PE teachers are not able to maintain a TPSR mandate the effectiveness of TPSR interventions may be limited which may imply the use of post-intervention designs.

Finally, many contexts have been explored to understand how to integrate TPSR with promising results. Nevertheless, few studies have focused on investigating the implementation of TPSR with children ranging between 3 and 10 years old. One of the contexts that has been less explored is preschool education which has been considered a crucial context to teach personal and social skills both in Portugal and Spain. Thus, research that expands beyond adolescent youth is warranted.

\section{Practical Implications}

Considering the increased attention given to TPSR in Portugal and Spain within research forums and PE curriculum (Escartí et al., 2012; Martins et al., 2015; Silva, Marques, Mata, \& Rosa, 2016), research on life skills transfer could contribute to a more general understanding that using a TPSR framework to teach personal and social responsibility to youth could add value and generate highly impactful developmental experiences. In this section, we will attempt to provide practical implications for teachers and other stakeholders based on the reflections provided in this review.

We suggest that stakeholders involved in a vast array of settings attempt to deliberately plan, implement and assess life skills transfer. A first step would be to understand youth participants responsibility behaviors and developmental needs through available measures and/or observational tools. Second, teachers and/or coaches could define differentiated instruction techniques that enable the creation of appropriate developmental opportunities for all. Within these efforts, several decisions may need to be made and answers provided to these questions: (a) which life skills should be transferred at this developmental stage?; (b) which context should life skills be transferred to (e.g., playground, other content areas, 
sport clubs)?. Finally, systematic efforts are needed to attain better responsibility outcomes. Concurrently, teachers and/ or coaches should attempt to continuously assess their own practice and seek for learning opportunities that meet their needs either formal (e.g., teacher education program) and/or informal (e.g., discussions with a mentor). This process includes becoming aware about social influences and pressures that directly impact their ability to foster TPSR and remaining open to develop alternative strategies and adaptations that still allow for TPSR key values to be in place and benefit youth. For teachers working with children ranging between 3 and 10 years old, this process is of the utmost importance due to the fact they can contribute to the creation of knowledge and positively influence their peers about the need for a TPSR approach.

These suggestions may serve as crucial for stakeholders interested in TPSR in Portugal and Spain and help them translate knowledge into practice. However, we should have in mind that there is still much to understand and explore about how TPSR may help youth flourish.

\section{Future Directions}

Considering the reflections provided in this article, there are several future directions that may need to be explicitly stated to help move the field forward in Portugal and Spain. In order to move the field forward, there is the need to understand which responsibility outcomes, factors that influence TPSR and educational settings/populations need to be explored (Corte-Real, Dias, Regueiras, \& Fonseca, 2016). Considering previous studies with TPSR (André \& Mandigo, 2013; Belando, Ferriz-Morell, \& Moreno-Murcia, 2012; Coulson, Irwin, \& Wright, 2012), these three themes (i.e., responsibility outcomes, factors that influence TPSR, and educational settings/populations) have been extensively discussed within the TPSR literature and deserve reflection (Caballero-Blanco, Delgado-Noguera, \& Escartí-Carbonell, 2013).

A hybrid analysis that allows a combined understanding of the adaptations needed to implement TPSR (i.e., process evaluation) and youth participants' responsibility outcomes (i.e., outcome evluation) has been less explored in previous studies conducted in Portugal and Spain (Esperança, Regueiras, Brustad, \& Fonseca, 2013; Pavão et al., 2019; Santos et al., 2017). In other words, most studies either conducted an outcome or a process evaluation. Hellison's (2011) initial premise regarding TPSR was to provide guidelines for PE teachers to view PE as a developmental setting and prompt reflections on the adaptations needed to implement TPSR within specific educational settings. Thus, the aim was not to guide PE teachers to follow a rigid set of activities, objectives, and strategies. Moving forward, there is still the need to understand teachers' thought processes while creating a TPSR-based program, access adaptations made within specific educational settings, and existent barriers to implementation. In other words, a more detailed analysis (e.g., decisions made, rationale for these decisions) of how PE teachers create, adapt, and continuously plan and implement a TPSR program could prove useful. Future research could help understand teachers and programmers decisions prior and during TPSR interventions through reflexive journaling and focus groups and revisit the decisions made through stimulated recall interviews (Lyle, 2003).

TPSR represents in a broad sense a way of operationalizing youth development in PE. Understanding how implementation occurs could facilitate a more complete understanding about the processes that allow PE teachers to translate theory into practice. For example, if a TPSR-based program is implemented in a preschool setting, understanding how PE teachers use TPSR and the vast array of decisions teachers make to fit the core premises of the TPSR to this particular educational context, children's needs, and curriculum would be useful for both pre-service and in-service teacher education. These adaptations are culturally situated and could, potentially, increase our knowledge regarding how TPSR is and could be used. Futures studies that use methodologies such as action-research (MacDonald, 2012) might prove useful due to the focus placed on experiences, meanings and PE teachers' thought process as they navigate within problem identification, investigation and application/ assessment. Action-research designs could provide a set of evidence-based recommendations for practice and enhance our knowledge base. Entering PE teachers' thought processes could increase our understanding on how adaptations occur and why, and this could help PE teachers struggling to envision how to use TPSR in their own settings and sensitize them to potential challenges.

There is also the need of a body of literature that could reflect which life skills transfer outcomes derived from TPSRbased programs are attained. Recently, Kendellen and Camiré (2019) alluded to the notion that longitudinal designs that go beyond interviews are needed. Based on this notion, it might be prudent develop research designs aimed at understanding the transfer processes within PE and beyond PE. For example, if a TPSR-based programming targeting underserved youth is implemented, understanding how life skills are transferred to the household by analyzing parents' perspectives on life skills transfer would be beneficial. This information could help inform PE teachers' implementation processes and increase the ability to understand if and how life skills transfer is actually occurring. Accordingly, research of this type raises the need for clear definitions of: (a) responsibility outcomes targeted within a TPSR-based program, (b) the target setting for life skills transfer, and (c) which stakeholders play a role in life skills transfer processes. Based on previous notions, researchers reflecting on how to investigate TPSR could potentially study the flexible and dynamic nature of the creation and implementation of a TPSR-based program based on the cultural ramifications prevalent in Portugal and Spain. Considering these three guidelines, these studies could use multiple perspectives from stakeholders (e.g., parents, teachers) relevant for the life skills transfer process to capture their perceptions through qualitative designs and observe, when possible, students behaviors beyond the program (e.g., in other courses in school beyond PE) through observational grids such as the TARE. We also suggest that researchers attempt to develop research designs that enable an understanding about how TPSR impacts each youth participant and that capture teachers differentiated instruction techniques. Melo’s et al. (in press) observational grid to cap- 
ture differentiated instruction techniques used by the teacher and students diverse responsibility behaviors might be a valuable tool to answer this research question.

Considering social influences on TPSR, several questions could be raised within the Portuguese and Spanish context: What are the post-intervention effects of a TPSR-focused teacher education programs? How are PE teachers navigating the challenges of maintaining a TSPR mandate without any support for trainers and/or experts on TPSR? For example, research designs that include TPSR-focused teacher education could attempt to discern how PE teachers are able to apply PYD materials at the post-education phase, the challenges faced while delivering TPSR-based programs, and the strategies used to overcome them. The information attained through this analysis could then be used to develop TPSR-focused teacher education programs to better prepare PE teachers to implement TPSR and sustain a TPSR direction over time. These studies could use a mixed-methods approach to get a nuanced understanding about how teachers maintain a TPSR mandate and how it impacts youth. Agood example of such an approach is Camerino's et al. (2019) mixed-methods study that monitored teacher behaviors after TPSR training. For example, a PE teacher might feel pressured to change his approach and disregard TPSR because the PE department is comprised of teachers who are not intrinsically motivated to develop the associated PSR skills and simply focus on psychomotor skills and performance at local school sport events. At the same time, the school manager might not provide opportunities for the PE teacher to reflect and continuously learn to implement the TPSR and refine specific teaching skills as other content areas could be considered more important. Then, the PE teacher might change his pedagogical approach to fulfill the school manager's expectations, feel integrated within that social structure, and devote less time to reflecting on TPSR.

A stronger focus on how PE teachers learn, create, implement, and sustain TPSR-based programs would offer insight on the challenges and barriers and associated to embedding TPSR within the school curriculum. Research on TPSR has yet to analyse how PE teachers overcome the challenge of sustainability as more controlled interventions have been conducted in many cases delivered by experts on TPSR (Blanco et al., 2013; Escartí et al., 2010).

Moving forward, assuming the complex nature of delivering TPSR-based curricula (Hellison, 2011) the exploration of the social forces that may hinder or facilitate TPSR implementation, particularly within countries such as Portugal and Spain where TPSR is still begining to become a more accepted perspective on teaching youth might serve useful in understanding implementation successes and struggles. Conceiving, delivering, and maintaining a TPSRbased program could be viewed as a result of cooperative learning and a product of the interactions with the different members that make up the school community (Silins, Zarins, \& Mulford, 2002). This approach may support the need for researchers to analyse PE teachers' learning paths and processes, and develop studies that focus on how PE teachers learn to implement TPSR and, how they 'learn to learn' which may be key for program sustainability. Considering that, in some cases, socially constructed perspectives could lead to 'toxic mutations' that are not aligned with core TPSR premises (Richards \& Gordon, 2016). Future studies could, potentially, analyse the adaptations needed to implement TPSR within preschool education. For example, the exploration of the experiences of preschool teachers while adapting TPSR, the existent challenges and strategies used, would enable the development of teacher education programs to meet their specific needs. Finally, future research designs could also attempt to understand, longitudinally, the impact of implementing TPSR from childhood through adolescence. The need to focus on the initial developmental phases (i.e., childhood) could drive researchers to conceptualize research projects and target less studied populations and educational settings.

Based on these notions, future studies could focus on understanding the process behind implementing SEL as TPSR across subject areas within preschool education through action-research designs among other methodologies that capture the intricacies experienced in these settings. This avenue could help provide broader conceptual portrait about personal and social responsibility how TPSR could be used within the school setting as a mechanism to teach what appear to be nebulous constructs.

\section{References}

Alcalá, D., Río, J., Calvo, G., \& Pueyo, Á. (2019). Comparing effects of a TPSR training program on prospective physical education teachers' social goals, discipline and autonomy strategies in Spain, Chile and Costa Rica. Physical Education and Sport Pedagogy, 24(3), 220-232 doi: 10.1080/17408989.2018.1561837

André, M. H., \& Mandigo, J. L. (2013). Analyzing the learning of the taking personal and social responsability model within a new physical education undergraduate degree program in El Salvador. The Physical Educator, 70, 107-134.

Bakken,L.,Brown, N., \& Downing,B.(2017).Early childhoodeducation: Thelong-termbenefits. Journal of Research in ChildhoodEducation, 31(2), 255-269.

Barker, B., \& Forneris, T. (2012). Reflections on the implementation of TPSR programming with at-risk-youth in the city of Ottawa, Canada. Agora para la Educación Física yel Deporte, 14(1), 7893.

Bean, C., Kramers, S., Forneris, T., \& Camiré, M. (2018). The implicit/ explicit continuum of life skills development and transfer. Quest, 70(4), 456-470.

Belando, N., Ferriz-Morell, R., \& Moreno-Murcia, J.A. (2012). Propuesta de un modelo para la mejora personal y social a través de la promoción de la responsabilidad en la actividad físico-deportiva. Revista internacional de ciencias del deporte, 29(8), 202-222.

Blanco, P.(2015). Diseño, implementación y evaluación de un programa de actividades en la naturaleza para promover la responsabilidad personal y social en alumnos de formación profesional. Cuadernos de Psicología del Deporte, 15(2), 179-194.

Blanco, P.C., Delgado-Noguera, M.-A., \& Escartí-Carbonell,A.(2013). Analysis of teaching personal and social responsibility modelbased programmes applied in USA and Spain. Journal of Human Sport \& Exercise, 8(2), 427-441.

Brustad, R., \& Parker, M. (2005). Enhancing positive youth development through sport and physical activity. Psychologica, 39(1), 75-93.

Camerino, O., Valero-Valenzuela, A., Prat, Q., Sánchez, D., \& Castañer, M. (2019). Optimizing education: A mixed methods approach 
oriented to teaching personal and social responsibility. Frontiers in Psychology, 10(1). doi: 10.3389/fpsyg.2019.01439

Cascales, J., \& Prieto, M. (2019). Incidencia de la práctica de actividad física y deportiva como reguladora de la violencia escolar. Retos, 35(1), 54-60.

Casey,A., \& Dyson, B. (2009). The implementation of models-based practice in physical education through action research. European Physical Education Review, 15(2), 175-199.

Coakley, J. (2016). Positive youth development through sport: Myths, beliefs, and realities. In Holt N.(Ed.), Positive youth development through sport (2nd ed., pp. 21-33). New York, NY: Routledge.

Collaborative for Academic, Social, andEmotional Learning(n.d.) What is SEL? Retrieved from https://casel.org/what-is-sel/

Côrte-Real, A. (2011). Escola, inclusão e responsabilidade pessoale social... : Que papel para o desporto? (Mestrado em Atividade FísicaAdaptada), Faculdade de Desporto da Universidade do Porto, Porto.

Correia, S. (2007). O desenvolvimento da responsabilidade pessoal e social, em crianças e jovens em risco de insucesso escolar, através de um programa desportivo: um estudo na escola do Ensino Básico do $2^{\circ}$ e $3^{\circ}$ Ciclos de Paços de Brandão. (Mestrado em treino de crianças e jovens), Faculdade de Desporto da Universidade do Porto, Porto.

Coulson, C., Irwin, C., \& Wright, P. (2012). Applying Hellison’s responsibility model in a youth residential treatment facility: A practical inquiry project. Agora para la Educación Física y el Deporte, 14(1), 38-54.

Damon, W. (2004). What is positive youth development? The Annals of the AmericanAcademy,591(1), 13-24.

Deci, E. L., \& Ryan, R. M. (2008). Self-determination theory: A macrotheory of human motivation, development, and health. Canadian Psychology, 49(3), 182-185. doi: 10.1037/a0012801

Duerden, M., \& Witt, P. (2012). Assessing program implementation: What it is, why it's important, andhow to do It. Journal of Extension, 50(1), 1-8.

Durlak, J., Weissberg, R., Dymnicki,A., Taylor, R., \& Schellinger, K. (2011). The impact of enhancing students' social and emotional learning: Ameta-analysis of school-based universal interventions. Child Development, 82(1), 405-432.

Ennis, C. D., Solmon, M. A., Satina, B., Loftus, S. J., Mensch, J., \& McCauley, M. T. (1999). Creating a sense of family in urban schools using the «Sportfor Peace» curriculum. Research Quarterly for Exercise and Sport, 70(3), 273-285.

Escartí, A., Sanmartín, M., Baños, C., Suelves, D., Taboada, C., \& Flores, Y. (2006). Enseñando responsabilidad personal y social a un grupo de adolescentes de riesgo: Un estudio «observacional». Revista de Educación, 341, 373-396.

Escartí,A., Gutiérrez, M., Pascual, C., \& Marín,D.(2010). Application of Hellison's teaching personal and social responsibility model in physical education to improve self-efficacy for adolescents at risk of dropping-out of school. The Spanish Journal of Psychology, 13(2), 667-676.

Escartí, A., Pascual, C., Gutiérrez, M., Marín, D., Martínez, M., \& Tarín, S. (2012). Applying the Teaching Personal and Social Responsibility Model(TPSR) in Spanish Schools Context: Lesson Learned.Agora para la Educación Físicayel Deporte, 14(2), 178196.

Escartí, A., Gutiérrez, M., Pascual, C., \& Wright, P. (2013). Observación de las estrategias que emplean los profesores de educación física para enseñar responsabilidad personal y social [Observation of the strategies that physical education teachers use to teach personal and social responsibility]. Revista de Psicologia del Deporte, 22(1), 159-166.

Escartí, A., Wright, P., Pascual, C., \& Gutiérrez, M. (2015). Tool for assessing responsibility-based education (TARE) 2.0: Instrument revisions, inter-rater reliability, and correlations between observed teaching strategies and student behavior. Universal Journal of Psychology,3(2), 55-63. doi: 10.13189/ujp.2015.030205

Escartí, A., Llopis-Goig, R., \& Wright, P. (2018). Assessing the implementation fidelity of a school-based teaching personal and social responsibility program in physical education and other subject areas. Journal of Teaching in Physical Education, 37(1), 12-23.

Esperança, J., Regueiras, L., Brustad, R., \& Fonseca, A. (2013). Um olhar sobre o desenvolvimento positivo dos jovens através do desporto. Revista de Psicologia del Deporte, 22(2), 481-487.

Ford, D., \& Lerner, R. (1992). Developmental systems theory: An integrative approach. Thousand Oaks, CA: Sage Publications.

Gordon, B. (2009). Merging teaching personal and social responsibility with sport education: Amarriage made in heaven or hell? Healthy Lifestyles Journal, 56(3), 13-16.

Gordon, B. (2010). An examination of the responsibility model in a New Zealand secondary school physical education program. Journal of Teaching in Physical Education, 29(1), 21-37.

Gordon, B., Thevenard, L., \& Hodis, F. (2012). Anational survey of New Zealand secondary schools physical education programs implementarion of the teaching personal and social responsibility (TPSR) model. Agora para la Educación Física y el Deporte, 14(2), 197-212.

Gould, D., \& Carson, S. (2008). Life skills development through sport: Current status and future directions. International Review of Sport \& Exercise Psychology, 1(1), 21-58.

Hamre, B., \& Pianta, R...(2005). Caninstructional and emotional support in the first-grade classroom make a difference for children at risk of school failure? Child Development, 76(5), 949-967.

Hastie, P., Ojeda, D., \& Luquin, A. C. (2011). Areview of research on Sport Education: 2004 to the present. Physical Education and Sport Pedagogy, 16(2), 103-132.

Hellison, D.(2011). Teachingpersonal and social responsability through physical activity (3. ${ }^{\mathrm{a}}$ ed.). Champaign, IL: Human Kinetics.

Hellison, D., Martinek, T., \& Cutforth, N. (1996). Beyond violence prevention in inner-city physical ativity programs. Journal of Peace Psychology,2(4), 321-337.

Hemphill, M., Templin, T. J., \& Wright, P. M.(2015). Implementation and outcomes of a responsibility-based continuing professional development protocol in physical education. Sport,Education and Society, 20(3), 1-22.

Holt, N. (2016). Positive youth development through sport (2a ed.). London, UK: Routledge.

Jacobs, J., \& Wright, P. (2017). Transfer of life skills in sport-based youth development programs: A conceptual framework bridging learning to application. Quest, 70(1), 81-99.

Jung, J., \& Wright, P. (2012). Application of Helisson's responsibility model in South Korea: A multiple case study of 'at-risk' middle school students in physical education. Agora para la Educación Física yel Deporte, 14(2), 140-160.

Kendellen, K., \& Camiré, M. (2019). Going beyond the interview: Methodological considerations for «getting at» life skills transfer using a longitudinal integrated qualitative approach. Qualitative Researchin Sport, Exercise and Health, Advanceonline publication.

Lawson, H.A. (1983a). Toward a model of teacher socialization in physical education: The subjective warrant, recruitment, and teacher ediucation (part 1). Journal of Teaching in Physical Education, 2(3), 3-16.

Lawson, H.A. (1983b). Toward a model of teacher socialization in physical education: Entry into schools, teachers' role orientations, and longevity in teaching (part 2). Journal of Teaching in Physical Education, 3(1), 3-15.

Lerner, R., Almerigi, J., Theokas, C., \& Lerner, J. (2005). Positive 
youth development: A view of the issues. The Journal of Early Adolescence, 25(1), 10-16.

MacDonald, C. (2012). Understanding participatory action research:A qualitative research methodology option. Canadian Journal of Action Research, 13(2), 34-50.

MacDonald, D. J., \& McIsaac, T. (2016). Quantitative assessment of positive youth development in sport. In N. Holt (Ed.), Positive youth development through sport (pp. 83-96): Routledge.

Martinek, T., \& Hellison, D. (2009). Youth leadership in sport and physical education. New York, NY: Palgrave Macmillan.

Martinek, T., \& Hellison, D. (2016). Teaching personal and social responsibility: Past, present and future. Journal of Physical Education, Recreation \& Dance, 87(5), 9-13.

Martinek, T., Schilling, T., \& Hellison, D. (2006). The development of compassionate and caring leadership among adolescents. Physical Education and Sport Pedagogy, 11(2), 141-157.

Martins, P., Rosado,A., Ferreira, V., \& Biscaia, R. (2015). Examining the validity of thepersonal-social responsibility questionnaire among athletes. Motriz. Revista de Educação Física, 21(3), 321-328.

McLennan, N. \& Thompson, J. (2015). Quality physical education (QPE). Guidelines for policy-makers. Paris, France: UNESCO.

Melo, M., Santos, F., Wright,P., Sá, C., Saraiva,L. (in press). Strengthening the connection between differentiated instruction strategies and teaching personal and social responsibility: Challenges, strategies and future pathways. Journal of Physical Education, Recreation \& Dance.

Merino-Barrero, J., Pedreño, N., Valenzuela,A., \& Fernandez-Rio, J. (2019). Impact of a sustained TPSR program on students' responsibility, motivation, sportsmanship, and intention to be physically active. Journal of Teaching in Physical Education, Advance online publication.

Molina,F.(2018). Educación física, calidad de viday la nueva sociología dela infancia: Repensando la metodología mixta en sociología. Retos, 33(1), 69-73.

Neves, R. (2017). Escolas, professores e educação física: Responsabilidades, gestãoe profissionalidadeno primeiro ciclo do ensino básico. Sociedade Portuguesa de Educação Física, 32(1), 107-119.

Pavão, I., Santos, F., Wright, P., \& Gonçalves, F. (2019). Implementing the teaching personal and social responsibility model within preschool education: strengths, challenges and strategies. Curriculum Studies in Health and Physical Education, 10(1), 51-70.

Phelps, E., Zimmerman, S., Warren,A., Jeliè, H., Eye, A., \& Lerner, R. (2009). The structure and developmental course of Positive Youth Development(PYD) in early adolescence: Implications for theory and practice. Journal of Applied Developmental Psychology,30(5), 571-584.

Pierce, S., Gould, D., \& Camiré, M. (2017). Definition and model of life skills transfer. International Review of Sport \& Exercise Psychology, 10(1), 186-211.

Pill, S., Penney, D., \& Swabey, K. (2012). Rethinking sport teaching in physical education: A case study of research based innovation in teacher education. Australian Journal of Teacher Education,37(8), 118-138.

Ponsoda, F. (2014). Efectos, en los adolescentes, de un programa de responsabilidad personal ysocial a través del deporte extraescolar. (Tesis Doctorales), Universidad d'Alacant,Alicante.

Pozo, P., Grao-Cruces, A., \& Pérez-Ordás, R. (2018). Teaching personal and social responsibility model-based programmes in physical education: A systematic review. European Physical Education Review, 24(1), 56-75.

Puente-Maxera, F., Mahedero-Navarrete, M., Méndez-Giménez,A., \&Ojeda,D.(in press). Educación deportiva, roles y vulnerabilidad: Influencia en la responsabilidad einterculturalidad. Revista Internacional de Medicina y Ciencias de la Actividad Física yel Deporte,
Advance onlinepublication.

Regueiras, L. (2006). Desenvolvimento da responsabilidade pessoale social de jovens em risco, através do desporto: Será possível? (Mestrado em Atividade Física Adaptada), Faculdade de Desporto da Universidade do Porto, Porto.

Richards, A., \& Gordon, B. (2016). Socialisation and learning to teach using the teaching personal and social responsibility approach. Asia-Pacific Journal of Health, Sportand Physical Education, 8(1), 19-38.

Ruiz, L. M., Rodríguez, P., Martinek, T., Schilling, T., Durán, L. J., \& Jiménez, P. (2006). El proyecto Esfuerzo: Un modelo para el desarrollo de la responsabilidad personal y social a través del deporte. Revista de Educación, 341, 933-958.

Santos, F., Corte-Real, N., Regueiras, L., Wright, P., Dias, C., \& Fonseca, A. (2019). Tool for assessingresponsibility-basededucation(TARE) in the Portuguese context: Instrument adaptation and reliability assessment. Ibero-American Journal of Exercise and Sports Psychology, 14(2), 102-107.

Santos, F., Corte-Real, N., Regueiras, L., Dias, C., \& Fonseca,A. (2017). A perspetiva do professor de educação física na implementação do modelo de desenvolvimento da responsabilidade pessoal e social. Sociedade Portuguesa de Educação Física, 40(1), 69-76.

Santos, F., Côrte-Real, N., Regueiras, L., Farias, C., Moreno-Murcia, J., \& Dias, C. (2015). Aaplicação do modelo de desenvolvimento da responsabilidade pessoal e social a crianças em risco de exclusão social: Um estudo de investigação-ação. Revista Portuguesa de Ciências do Desporto, 15(3), 13-28.

Silins, H., Zarins, S., \& Mulford, B. (2002). What characteristics and processes define a school as a learning organisation? Is this a useful concept to apply to schools? International Education Journal, 3(1), 24-32.

Theokas, C., Almerigi, J. B., Lerner, R. M., Dowling, E. M., Benson, P. L., Scales, P.C., \& Eye,A.v.(2005). Conceptualizing and modeling individual and ecological asset components of thriving in early adolescence. The Journal of Early Adolescence, 25(1), 113-143.

Valero,A., Martínez, S., \& Botella, J. (in press). Metodología cooperativa para la mejora de actitudes disruptivas en educación física. Revista Internacional de Medicina y Ciencias de la Actividad Física yel Deporte, Advance online publication.

Vivas, M., Gómez, J., Bartoll, O., \& Miravet, L. (2017). Validación de uninstrumento de observación para el análisis de habilidades socioemocionales en Educación Física. Retos, 31(1), 8-13.

Walsh, D., Ozaeta, J., \& Wright, P.(2010). Transference of responsibility model goals to the school environment: Exploring the impact of a coaching club program. Physical Education and Sport Pedagogy, 15(1), 15-28.

Whitley, M., Forneris, T., \& Barker, B. (2015). The reality of sustaining community-based sport and physical activity programs to enhance the development of underserved youth: Challenges and potential strategies. Quest, 67(4), 409-423.

Wright, P., Dyson, B., \& Moten, T.(2012). Exploring theindividualized experiences of participants in a responsability-based youth development program. Ágora para la EF yel Deporte, 14(2), 248263.

Wright, P., Jacobs, J., Ressler, J., \& Jung, J. (2016). Teaching for transformative educational experience in a sport for development program. Sport, Education and Society, 21(4), 531-548.

Wright,P., White,K., \& Gaebler-Spira,D.(2004). Exploring therelevance of the personal and social responsibility model in adapted physical activity: A collective case study. Journal of Teaching in Physical Education, 23(1), 71-87. 